\section{Rick's North American Art Museum Ranking List}

Richard J. Barohn, MD

In the pre- Covid era, we all did a lot more traveling! I estimate I was traveling 3 to 4 times a month for various academic events and meetings. I was able to visit many cities over my academic career... some over and over and over. I must admit one of the things I am enjoying in this difficult time of the covid pandemic is that I am not traveling now. I like it. Sometimes I wonder "what was I thinking over the last 40 years doing all of that travel??"

But one advantage to all of the academic travels was that I was able to visit many art museums and I was able to feed my deep interest in viewing art. I am not an artist and have no artistic ability. But I enjoy looking at art enormously and it has been a big part of my life. I have a bit of an art collection but of course most of it is not museum quality art. To see that level of art you need to view it in museums. I started making it a habit that each time I visited a city I tried to find a bit of time, even if it was a couple of hours (sometimes even an hour!) , to visit the local art museum. I got to know many of these museums well, and the museums and the art in their walls became good friends that I would go back to view over and over.

About five years ago I got the idea to begin ranking the art museums i was visiting. I think this was when we began doing our traveling Neuromuscular CME course and we would go to one or two cities a month, covering up to 10 cities a year. We (Mazen Dimachkie, Todd Levine, Jon Katz and I) did these courses on Saturday's so I would find time on Friday afternoon or Sunday morning to get to the local museum.

We rank things all the time in our academic lives, be it reviewing grants, or journal articles, or resident and fellow applicants. We are used to ranking things. Now it may be very presumptuous for a neurologist to think he can rank art museums $\rightarrow$ and I acknowledge that fact and that I am surely an amateur. Nevertheless... I started ranking museums. I decided to stick with art museums in North America. Why?

The museums in France, United Kingdom, Spain, Italy are phenomenal. and we probably have one or maybe two art museums in the USA that can compete with the Louvre, the National Art Gallery of England, the Prado and the Ufizi and the Vatican museum. Maybe one day I will try to do that ranking, but it would be a challenge. So i stuck with North American museums and that was hard enough.

I came up with a scoring system on a 1 to 5 scale with 1 being wors/ 5 best. And I came up with 5 categories. The first two are somewhat self-explanatory:

Quality: This sort of speaks for itself. On average what is the quality of the art?

Quantity: How much art is in the museum?

The next two may take some explanation:

Depth: how much art is there in the various areas of the collection? For example, do they have just one Rembrandt or 5 ? One or two pieces of art from the Italian renaissance or a dozen? One Monet or several? A few impressionist works of art or 20 ?

Range: does the museum just collect American art? Or does it collect art from around the world? For example, the Metropolitan Museum of Art (the MET) in New York City collects just about everything. On the other hand, the Museum of Modern art (MOMA) in New York City collects just modern art, essentially since the turn of the century and most since world war 2 . So while the MOMA is a fabulous art museum that ranks very high in quality, quantity, and depth in what they collect, in the range category it ranks low. I have had arguments with an art Curator friend of mine who was aghast that I did not have the MOMA in the top 5. I tried to explain why but she would not hear it. For her quality trumped all! Nevertheless, I have stuck with this approach. Maybe it's an amateur approach but its Rick's approach :)

Then I have a final category that I call: Building and Environment. I decided, after visiting so many museums, that I could weigh in on:

How good was the building?,

If it was old, had it been kept up physically? If

it was new, was it an improvement?

How was the art laid out for viewing? Did I get lost easily?

Was the temperature ok?

How good were the bathrooms? Where they hard to find? 
Was it hard to read the labels about the art?

Did they go above and beyond to give extra information about the art pieces and the collection? Did they make an attempt to provide an educational program?

How good was the food service area? How good was the museum store?

Each time I went to the museum I would try to rank it and write down my numbers immediately after the visit. If I had visited it and ranked it before, I updated my rankings and noted the date. I put all of this on an excel spread sheet. I decided to have two averages for each museum: the average of the 4 art categories (Quality, Quantity, Range, Depth) and then a column with the average of all 5 categories, that included the Building and Environment.

Whenever I tell folks I have this Rick's North American Museum Rankings data, they of course want to know two things:

What are the top/best museums?

How did my local museum rank?

Regarding the top ranked, the MET and the National Gallery in wash DC ranked the highest....both all 10s in the four art categories. However, if we add the building/environment category the National Gallery wins due to its wonderful buildings and facilities, both east and west structures that are connected underground. While the art in the MET is just extraordinary, I cringe every time I go in the old, confusing building. I get lost every time I visit it. Where can you eat/drink in peace? And where are the bathrooms? I really don't like that building. The Art Instutute of Chicago comes in at a solid 3. For years I had the Philadelphia museum of Art as number 4 but then I finally got to the Detroit Art Museum in 2018 and what an amazing collection and building! So Phili got bumped down a notch. The other sleeper that broke into the top 10 was the Cleveland Museum of Art, which I finally got to when I attended a family wedding (can't miss the opportunity!). And Boston Museum of Fine Art was consistently in the top 5 until I visited the Detroit and Cleveland museums. But BMFA is still in the top 10, as is the MOMA. Again, it made the top 10 but only got a 5 in range.

Other sleepers that should get mentioned are the Indiana Museum of Art in Indianapolis on the old Lilly estate, the Minnesota Institute of Art, and the Speed Museum in Louisville. When I visited them I was amazed at the quality and breath of the collections. These museums, like the Detroit and Cleveland museums, are not walkable from downtown hotels. So you have to really want to get to these. They are at least a good half day visit as its unlikely you can just pop in and out of them when you are in the city like you can in New York, Wash DC, Boston, Phili, and Chicago.

And where does MY local art museum(s) rank? The Nelson-Atkins art museum is a jewel in the Midwest. I rank it at 17 with an art score of 6.5 and overall score of 6.8. My other local great art museum is the St. Louis Museum of Art which was the first art museum I visited as a teenager and probably got me hooked on art. I ranked St Louis at 20.

A couple of other points: I did not start putting dates of my last visit down until 2017. So some of the dates prior to that are estimates. I did visit all of the museums on the list except one: the Madison Museum of Contemporary Art in Madison, Wisconsin. My cousin Mark Wallis visited that one and I trust his impeccable art taste. He provided the rankings for that one. He tells me it's a gem.

Then there are the ones I have not visited yet. My bucket list. I list them at the bottom of the table. Who knows given the covid situation when I will get to these museums. If any of you want to weigh in on these and write a "what's on your mind" letter to the journal and fill us in on these art museums, please do that.

My next idea was to list the top five or 10 art pieces from each museum on the list. $\rightarrow$ another project and maybe another article.... 
Rick's North America Museum Rankings

\begin{tabular}{|c|c|c|c|c|c|c|c|c|c|}
\hline spt & 4 PARAMETERS & $6 v^{\sigma^{2}}$ & $0^{3 x^{5}}$ & $\theta^{\alpha^{+\lambda}}$ & o' & & & $\begin{array}{l}\text { OVERALL } \\
\text { AVG }\end{array}$ & LAST VISITED \\
\hline 1 & National Gallery, Smithsonian, Wash DC & 10 & 10 & 10 & 10 & 10 & 9 & 9.8 & $10 / 24 / 2018$ \\
\hline 2 & The Metropolitan Museum of Art, NYC & 10 & 10 & 10 & 10 & 10 & 3 & 8.6 & $11 / 10 / 2019$ \\
\hline 3 & The Art Institute of Chicago & 10 & 10 & 10 & 9 & 9.75 & 7 & 9.2 & $10 / 11 / 2018$ \\
\hline 4 & Detroit Institute of Arts & 10 & 9 & 8 & 8 & 8.75 & 10 & 9 & $8 / 12 / 2018$ \\
\hline 5 & Norton Simon Museum-Pasadena, CA & 8 & 10 & 9 & 6 & 8.25 & 10 & 8.6 & $3 / 13 / 2016$ \\
\hline 6 & Philadelphia Museum of Art & 8 & 9 & 8 & 8 & 8.25 & 4 & 7.4 & 2014 \\
\hline 7 & The Getty, Los Angeles, CA & 7 & 10 & 8 & 8 & 8.25 & 5 & 7.6 & $4 / 26 / 2018$ \\
\hline 8 & The Cleveland Museum of Art & 8 & 8 & 8 & 8 & 8 & 10 & 8.4 & $5 / 26 / 2017$ \\
\hline 9 & Museum of Fine Arts, Boston & 8 & 8 & 8 & 8 & 8 & 5 & 7.4 & 2018 \\
\hline 10 & MOMA-The Museum of Modern Art-NYC & 5 & 10 & 10 & 7 & 8 & 4 & 7.2 & $12 / 23 / 2018$ \\
\hline 11 & Indianapolis Museum of Art, Indiana & 8 & 9 & 7 & 8 & 8 & 5 & 7.4 & 2018 \\
\hline 12 & Barnes Foundation-Philadelphia, PA & 6 & 10 & 10 & 5 & 7.75 & 8 & 7.8 & 2014 \\
\hline 13 & Minneapolis Institute of Art, Minnesota & 8 & 7 & 7 & 8 & 7.5 & 5 & 7 & $5 / 14 / 2016$ \\
\hline 14 & The Museum of Fine Arts, Houston & 7 & 8 & 7 & 7 & 7.25 & 5 & 6.8 & $11 / 16 / 2019$ \\
\hline 15 & The Broad, Los Angeles, CA & 3 & 9 & 10 & 7 & 7.25 & 5 & 6.9 & $4 / 27 / 2018$ \\
\hline 16 & Kimbell Art Museum-Ft. Worth, TX & 7 & 10 & 5 & 5 & 6.75 & 10 & 7.4 & 2017 \\
\hline 17 & The Nelson-Atkins Museum of Art, Kansas City, MO & 7 & 7 & 6 & 6 & 6.5 & 8 & 6.8 & $9 / 1 / 2019$ \\
\hline 18 & Art Gallery of Ontario, Toronto, ON & 7 & 7 & 6 & 6 & 6.5 & 5 & 6.2 & $7 / 29 / 2017$ \\
\hline 19 & Yale Center For British Art, New Haven, CT & 1 & 9 & 10 & 6 & 6.5 & 8 & 6.8 & 2017 \\
\hline 20 & Saint Louis Art Museum & 7 & 7 & 6 & 6 & 6.5 & 7 & 6.6 & $7 / 11 / 1905$ \\
\hline 21 & Baltimore Museum of Art & 6 & 7 & 7 & 6 & 6.5 & 5 & 6.2 & $8 / 5 / 2017$ \\
\hline 22 & Los Angeles County Museum of Art & 6 & 6 & 6 & 7 & 6.25 & 7 & 6.4 & 2017 \\
\hline 23 & Joslyn Art Museum - Omaha, NE & 7 & 7 & 5 & 6 & 6.25 & 8 & 6.6 & $11 / 13 / 2016$ \\
\hline 24 & National Portrait Gallery/Smithsonian Art Musum, [ & & 7 & 7 & 7 & 6.25 & 8 & 6.6 & $9 / 25 / 2018$ \\
\hline 25 & The Speed Art Museum-Louisville, KY & 7 & 6 & 6 & 6 & 6.25 & 9 & 6.7 & $9 / 8 / 2018$ \\
\hline 26 & Crystal Bridges Museum of American Art-Bentonvill & 4 & 8 & 7 & 6 & 6.25 & 10 & 7 & $11 / 2 / 2019$ \\
\hline 27 & The Frick Collection-New York & 5 & 10 & 5 & 4 & 6 & 10 & 6.8 & $11 / 8 / 2019$ \\
\hline 28 & Isabella Stewart Gardner Museum, Boston & 5 & 9 & 6 & 4 & 6 & 9 & 6.6 & 2018 \\
\hline 29 & The Phillips Collection,Wash DC & 6 & 9 & 4 & 4 & 5.75 & 9 & 6.4 & $3 / 7 / 2018$ \\
\hline 30 & McNay Art Museum, San Antonio & 7 & 7 & 5 & 4 & 5.75 & 8 & 6.2 & 2015 \\
\hline 31 & Timken Museum of Art-San Diego, CA & 5 & 6 & 6 & 6 & 5.75 & 7 & 6 & 2015 \\
\hline
\end{tabular}




\section{Rick's North America Museum Rankings}

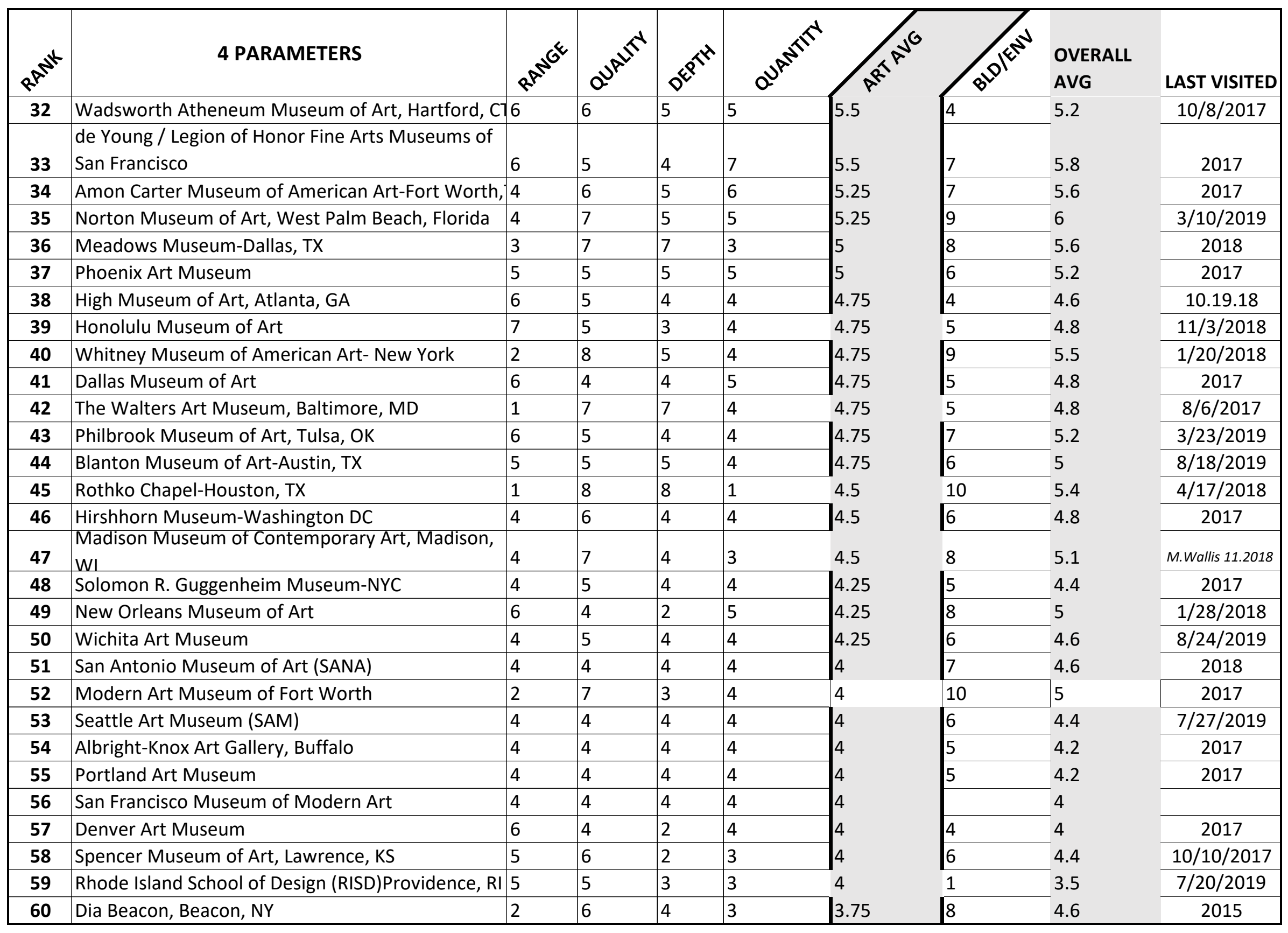


Rick's North America Museum Rankings

\begin{tabular}{|c|c|c|c|c|c|c|c|c|}
\hline $6 p^{p t}$ & 4 PARAMETERS & apt & $a^{p^{4}}$ & 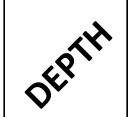 & 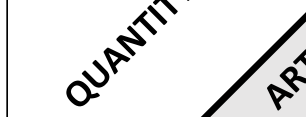 & & $\begin{array}{l}\text { OVERALL } \\
\text { AVG }\end{array}$ & LAST VISITED \\
\hline 61 & The Menil Collection - Houston, TX & 3 & 5 & 4 & 3.75 & 8 & 4.6 & 2016 \\
\hline 62 & $\begin{array}{l}\text { Nerman Museum of Contemporary Art; Johnson } \\
\text { County Community College,Overland Park, KS }\end{array}$ & 3 & 3 & 3 & 3.25 & 6 & 3.8 & 2019 \\
\hline 63 & The Montreal Museum of Fine Arts & 3 & 3 & 4 & 3.25 & 3 & 3.2 & 2017 \\
\hline 64 & Oklahoma City Museum of Art & 3 & 3 & 3 & 3 & 7 & 3.7 & $11 / 10 / 2017$ \\
\hline 65 & The Art Museum of South Texas-Corpus Christi, TX & 3 & 3 & 3 & 3 & 6 & 3.6 & 2015 \\
\hline 66 & Yale University Art Gallery, New Haven, CT & 4 & 4 & 2 & 2 & 8 & 4 & \\
\hline 67 & Kemper Museum of Contemporary Art-Kansas City, MO & 3 & 3 & 3 & 2.75 & 8 & 3.8 & 2019 \\
\hline 68 & Vancouver Art Gallery & 2 & 2 & 4 & 2.5 & 1 & 2.3 & 2017 \\
\hline 69 & Orlando Museum of Art & 3 & 4 & 2 & 2.5 & 3 & 2.6 & $4 / 13 / 2018$ \\
\hline 70 & Boise Art Museum & 2 & 3 & 2 & 2.25 & 5 & 2.8 & $8 / 12 / 2017$ \\
\hline 71 & The Mennello Museum of American Art Orlando & 1 & 4 & 2 & 1 & 3 & 2.2 & $4 / 15 / 2018$ \\
\hline 72 & Perez Art Museum Miami & 1 & 2 & 2 & 1.75 & 6 & 2.6 & 2017 \\
\hline \multirow[t]{14}{*}{73} & The Bass, Miami, FL & 1 & 2 & 0 & 1 & 2 & 1.7 & $2 / 2 / 2018$ \\
\hline & BUCKET LIST: & & & & & & & \\
\hline & Columbus Museum of Art, $\mathrm{OH}$ & & & & & & & \\
\hline & Walker Art Center - Minneapolis, MN & & & & & & & \\
\hline & Cincinnati Art Museum, $\mathrm{OH}$ & & & & & & & \\
\hline & Contemporary Arts Center, Cincinnati, OH & & & & & & & \\
\hline & Milwaukee Art Museum, WI & & & & & & & \\
\hline & Clark Art Institute, Williamstown, MA & & & & & & & \\
\hline & Muscarelle Museum of Art - Williamsburg, VA & & & & & & & \\
\hline & Daum Museum of Contemporary Art Sedalia, MO & & & & & & & \\
\hline & Albrecht-Kemper Museum of Art, St. Joseph, MO & & & & & & & \\
\hline & Marianna Kistler Beach Museum of Art Manhattan, & & & & & & & \\
\hline & Glenstone Museum-Potomac, MD & & & & & & & \\
\hline & National Gallery of Canada-Ottawa & & & & & & & \\
\hline
\end{tabular}


Rick's North America Museum Rankings

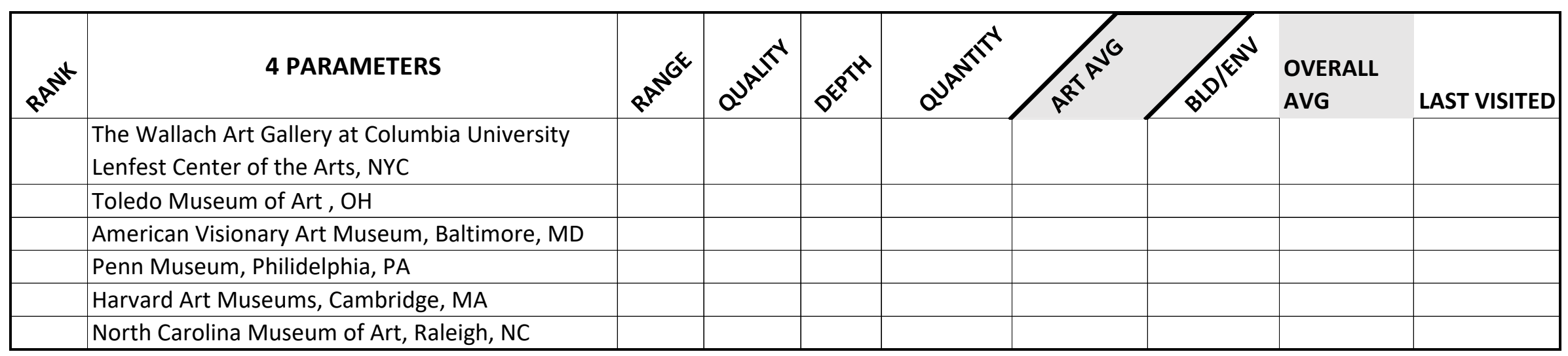

